\title{
HAMBATAN PENERAPAN KURIKULUM 2013 DI YAYASAN SMP ASSYIFA
}

\author{
${ }^{1}$ Melawati \\ ${ }^{1}$ FKIP Universitas Sultan Ageng Tirtayasa \\ e-mail:meymelawati49@gmail.com
}

\begin{abstract}
ABSTRAK
Penelitian ini bertujuan untuk memaparkan hambatan dalam sistem penerapan kurikulum 2013 di SMP ASYIFA. Kurikulum 2013 merupakan kurikulum yang baru, hal ini akan memicu terhadap kesiapan guru ketika berganti kurikulum dari KTSP ke kurikulum 2013, begitupun dengan kesiapan siswa dalam implementasi kurikulum 2013, dan sejauh mana keaktifan dalam kegiatan pembelajaran ketika dimulai. Jenis penelitian yang diambil oleh penulis yaitu kualitatif dan deskriptif yang dimana melihat langsung apa yang terjadi serta melakukan pendekatan untuk mendapatkan sumber data yang ada. Data yang dikumpulkan berupa hasil wawancara dan foto ketika kegiatan kelas dilaksanakan. Hasil penelitian menunjukan bahwa ketiga aspek kognitif, afektif dan psikomtorik berjalan lancar, kurangnya pemahaman mengenai K13, dan hambatan yang membuat K13 tidak berjalan lancar.
\end{abstract}

Kata kunci: Kurikulum 2013, aspek pendidikan, hambatan.

\section{ABSTRACT}

This study aims to explain the obstacles in the 2013 curriculum implementation system at ASYIFA Middle School. The 2013 curriculum is a new curriculum, this will lead to teacher readiness when changing the curriculum from KTSP to the 2013 curriculum, as well as student readiness in implementing the 2013 curriculum, and the extent of activeness in learning activities when it starts. The type of research taken by the writer is qualitative and descriptive, which sees firsthand what happened and approaches to obtain existing data sources. Data collected in the form of interviews and photos when class activities are carried out. The results showed that the three cognitive, affective and psychomtoric aspects went well, lack of understanding of K13, and obstacles that made K13 not run smoothly.

Keywords: 2013 curriculum, aspects of education, obstacle 


\section{PENDAHULUAN}

Pendidikan adalah proses mempengaruhi peserta didik dalam upaya menyesesuaikan diri dengan lingkungannya, artinya menimbulkan perubahan dalam diri peserta didik atau siswa didalam kehidupan masyarakat. Menurut, (UUR.I. No. 2 Tahun 1989, Bab I, Pasal 1) pendidikan adalah usaha sadar untuk menyiapkan peserta didik melalui kegiatan bimbingan, pengajaran, dan atau latihan bagi peranannya di masa yang akan datang. Dalam pendidikan tentunya memiliki fungsi dan tujuan didalamnya antara lain. Menurut (Dema Tesniyadi, 2018) Fungsi dan Tujuan Standar Nasional:

a) Standar Nasional Pendidikan berfungsi sebagai dasar dalam perencanaan, pelaksanaan, dan pengawasan pendidikan dalam rangka mewujudkan pendidikan nasional yang bermutu.

b) Standar Nasional Pendidikana bertujuan menjamin mutu pendidikan Nasional dalam rangka mencerdaskan kehidupan bangsa dan membentuk watak serta peradaban bangsa yang bermartabat.

c) Standar Nasional Pendidikan disempurnakan secara terencana, terarah, dan berkelanjutan sesuai dengan tuntutan perubahan kehidupan lokal. Nasional, dan global.

Adapun tujuan pendidikan menuruat, (UU Sisdiknas Pasal 3) Pendidikan Nasional bertujuan untuk mengembangkan kemampuan dan membentuk watak serta peradaban bangsa yang bermatabat dalam rangka mencerdaskan kehidupan bangsa, bertujuan untuk berkembangnya potensi peserta didik agar menjadi manusia yang beriman dan bertakwa kepada Tuhan Yang Maha Esa, berakhlak mulia, sehat, berilmu, cakap, kreatif, mandiri, dan menjadi warga Negara yang demokratis serta bertanggung jawab.

Implementasi merupakan suatu penerapan ide atau konsep, yang disusun dengan sistem matika yang baik. Seiring dengan perkembangan zaman yang dimana teknologi semakin canggih. Sistem pendidikan pun harus semakin diperbaiki, maka dari itu pemerintah mengganti kurikulum yang awalnya KTSP menjadi K13. Dalam K13 ini siswa dianjurkan untuk aktif dan kreatif.

Menurut (Oemar Hamalik, 2015) istilah "kurikulum" memiliki berbagai tafsiran yang dirumuskan oleh pakar-pakar dalam bidang pengembangan kurikulum sejak dulu sampai dengan dewasa ini. Tafsiran-tafsiran tersebut berbeda-beda satu dengan yang 
lainnya, sesuai dengan titik berat inti dan pandangan pakar bersangkutan. Istilah kurikulum berasal dari bahasa latin, yakni "Curriculae", Artinya jarak yang harus ditempuh oleh seorang pelari pada waktu itu, pengertian kurikulum ialah jangka waktu pendidikan yang harus ditempuh oleh siswa yang bertujuan untuk memperoleh ijazah.

Kurikulum 2013 (k-13) adalah kurikulum yang disahkan pemerintah untuk menggantikan kurikulum 2006 (KTSP). Kurikulum 2013 ini ketika saat memasuki masa percobaan yaitu pada tahun 2013 dibeberapa sekolah yang ditetapkan oleh pemerintah. Tepatnya dipertengahan tahun ajaran 2013/2014, ditahun 2013 pertama kalinya kurikulum diimplementasikan namun secara terbatas, yakni kelas I dan IV untuk tingkat sekolah dasar (SD), kelas VII tingkat SMP, dan kelas X tingkat SMA/SMK. Pada tahun 2014 kurikulum 2013 ini sudah diterapkan dikelas I, II, IV, dan V, untuk SMP kelas VII dan VIII, sedangkan di SMA Kelas X dan XI. (Kemendikbud, 2014).

Penyusunan kurikulum 2013 dimulai dengan menetapkan standar kompetensi kelulusan (SKL) yang sesuai dengan kesiapan peserta didik dan pendidikan nasional. Penerapan kurikulum 2013 menimbulkan kendala bagi sekolah, guru dan peserta didik. Diantaranya penambahann jam pelajaran perminggu menyulitkan pihak sekolah untuk mengembangkan kurikulum. Pada sekolah-sekolah swasta, kurikulum yang baru jelas menimbulkan masalah bagi yayasan, karena sekolah swasta dan yayasan harus memfasilitasi peningkatan guru berkualitas lewat pelatihan, pengadaan perpustakaan yang lengkap, dan pendidikan tambahan agar guru bisa mengimplementasikan kurikulum baru tersebut secara baik, dengan biaya ditanggung sendiri oleh pihak yayasan.

Guru mempunyai peranan penting dalam pelaksanaan kurikulum 2013, karna guru tidak dibebani dengan penyusunan silabus akan tetapi lebih mengarah untuk mengembangkan proses pembelajaran sesuai dengan pedoman kurikulum 2013 dan melaksanakan pembelajaran sesuai kompetensi-kompetensi pembelajaran. Selain itu para siswa yang terkadang mengeluh akan adanya perubahan dalam sistem pembelajaran yang ada, hal ini cenderung membuat siswa kewalahan. Namun, dampak yang terjadi juga memberikan sebuah pemahaman serta pemikiran para siswa menjadi terbuka dan sangat luas. 
SMP AS-SYIFA yang bertempatan di Desa Majau Kecamatan Saketi Kabupaten Pandeglang Provinsi Banten. Merupakan salasatu sarana pendidikan swasta yang mengimplementasikan Kurikulum 2013 dalam sistem pembelajaran dikelas.

\section{METODE}

Penelitian ini menggunakan metode penelitian kualitatif yang bersifat deskriftif yang dimana peneliti ingin melihat keadaan secara benar dan faktual mengenail implementasi kurikulum di SMP ASSYIFA, serta peneliti ingin mengambil data yang akurat dengan cara pendekatan kepada yang bersanguktan seperti guru dan siswa.

Menurut Bogan dan Taylor (1955) menjelaskan bahwa penelitian kualitatif adalah prosedur penelitian yang menghasilkan data deskriptif berupa kata-kata tertulis atau lisan dari orang-orang dan perilaku yang diamati. Sudah jelas bahwasannya metode kualitatif ini merupakan uraian kata dari pelaku yang dibentuk tulisan oleh peneliti. Alur penelitian meliputi:

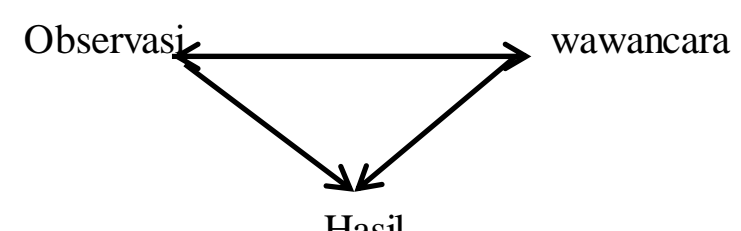

Hasil

\section{HASIL PEMBAHASAN}

\section{Pembelajaran}

Sistem pembelajaran adalah suatu hal yang telah tersusun meliputi berbagai macam prosedur yang adanya pemicu terhadap tujuan pendidikan. Yang artinya dimana pendidikan ini susunan dari konspe, unsur serta inovasi yang memiliki sebuah pengaruh terhadap tujuan pendidikan yang ada.

Menurut (Mc. Donald, 1959) pendidikan adalah suatu proses atau kegiatan yang bertujuan menghasilkan perubahan tingkah laku manusia. Hakikatnya pendidikan ini mengajarkan segala apapun dalam apapun yang dibutuhkan oleh manusia.

Dalam pendidikan tentunya memiliki aspek kognitif yang dimana kekampuan berfikir siswa akan terlihat, lalu aspek afektif sebuah perilaku dan nilai akan diajarkan 
dan diterapkan melalui pendidikan dikelas dan diluar kelas, selanjutnya aspek psikomotorik yang dimana siswa dilihat dalam aspek kemampuannya apakah hal yang telah dipelajari mampu diterapkan oleh diri siswa atau tidak. Berdasarkan ketiga aspek ini tentunya tidak terlepas dari pengaruh Kurikulum pendiidkan yang ada.

Saat peneliti melihat kegiatan pembelajaran siswa didalam kelas lebih tepatnya dikelas VIII SMP ASSYIFA yang berjumlah 40 siswa, peneliti dapat menyimpulkan siswa dalam pembelajaran sebagai berikut:

1. Siswa memiliki semangat dalam belajar,

2. Dalam segi pemahaman siswa tentu saat pembelajaran dimulai ada yang langsung memahami dan menyerap isi materi yang telah dijelaskan oleh guru ada pula yang sulit untuk menyerap materi dari gurunya.

3. Siswa dapat menghargai usaha temannya yang memiliki kemampuan lebih seperti halnya mampu memimpin diskusi kelompok dan lain-lain.

4. Sebagian siswa cenderung pasif dalam pembelajaran

Aspek kognitif yang cenderung menguji daya fikir siswa ini dapat memudahkan guru untuk melihat siapa saja yang aktif dan yang cepat dalam bertanggap disegi apapun dan siapa aja yang mengalami sebuah kesulitan dalam pembelajaran. Hal ini menjadikan sebuah tolak ukur yang nantinya akan ada perbedaan dalam pembelajaran, seperti seorang siswa yang kurang untuk menyerap sebuah ilmu pembelajaran hendaknya duduk dibarisan yang paling depan, guna memberikan kemudahan siswa untuk dapat berfikir dan berkonsentasi yang lebih. Karena pada umumnya siswa yang memiliki kekurangan dalam penyerapan materi itu merupakan kurangnya sebuah konsentrasi yang dimiliki oleh siswa karena pemikiran siswa yang berjalan kemana saja. 


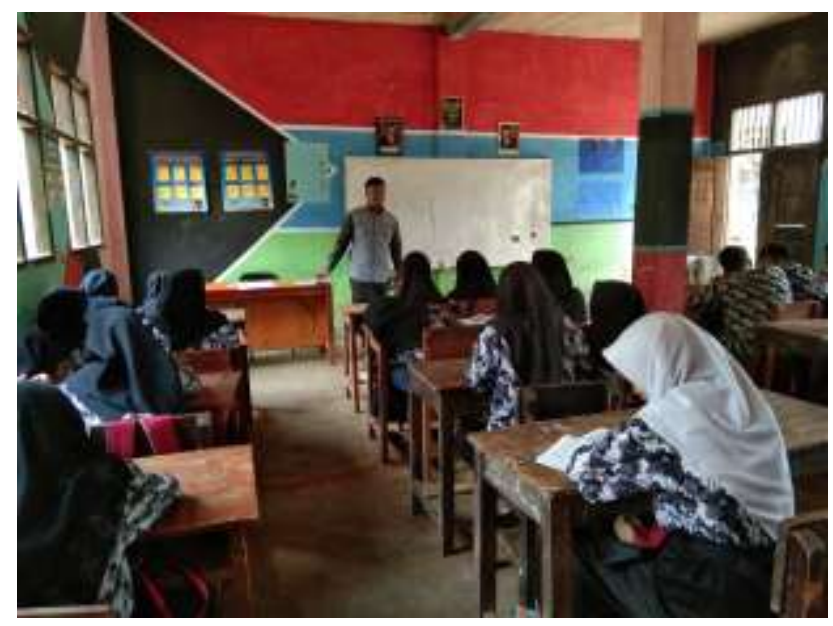

Gambar I. saat proses pembelajaran di dalam kelas (12 Maret 2020).

B. Aspek afektif (sikap dan penilaian)

Menurut Krathwolh, Bloom dan Masia (Oemar Hamalik, 2015) yang terdiri dari:

1. Penerimaan (receiving), suatu keadaan sadar, kemampuan untuk menerima, perhatian terpilih. Contohnya: siswa mempertunjukan kemampuan untuk mendengarkan rekaman musik rock, tetapi mengekpresikan perasaan yang lemah terhadap music tersebut.

2. Sambutan (responding), suatu sikap terbuka kearah sambutan kemauan untuk merespon; kepuasan yang timbul karena sambutan. Misalnya: siswa memutuskan untuk merespon pada lagu yang disajikan dan mengalami kesenangan atau kepuasan karenanya.

3. Menilai (valuing), penerimaan nilai-nilai, preferensi terhadap suatu nilai, membuat kesepakatan sehubungan dengan nilai. Conohnya: siswa menerima nilai musik dangdut, menghubungkannya dengan sistem nilainya sendiri, dan membentuk suatu kesepakatan sehubungan dengan pentingnya musik tersebut.

4. Organisasi (organization) suatu konseptualisasi tentang suatu nilai, suatu organisasi dari suatu sistem nilai. Contoknya: siswa menyatukan apresiasinya yang baru menjadikan kedalam sistem nilainya sendiri mengenai musik atau kultur lainnya.

5. Karakterisasi dengan suatu kompleks nilai, suatu formasi mengenai perangkat umum, suatu menifestasi daripada kompleks nilai. Contohnya: siswa menyatukan 
nilai musik kedalam kehidupan pribadi dan menyerap konsep tersebut pada hobi pribadinya, atau minat atau karirnya.

Dalam penilaian aspek afektif di SMP ASSYFA, peneliti mendapatkan bahwasannya hal dalam segi sikap dan penilaian dalam proses pembelajaran serta pendidikan merupakan hal dimana siswa memiliki penilaian sendiri namun aspek penilaian ini serta sikapnya harus sama seperti aturan yang berlaku disekolah tersebut.

Dalam Kurikulum 2013 ini siswa dianjurkan agar dapat memiliki sikap yang baik serta penilaian yang baik pula, karena dalam aspek K13 merupakan perombakan dari segala kurikulum guna untuk meningkatkan kedisiplinan serta jiwa yang baik kepada siswa.

Penilaian sikap bisa dari segi apapun bahkan dari segi interaksi antara guru dan siswapun bisa disebut kedalam aspek afektif ini, karena siswa telah dibekali oleh pengetahuan yang cukup maka tentunya siswa tersebut akan lebih mengerti terhadap perilaku serta sikap yang baik.

Data yang diperoleh peneliti dalam aspek afektif ini yaitu:

1. Siswa menerapkan budaya sopan santun, seperti pengucapan salam kepada guru dan lainnya.

2. Siswa menjaga cara bicaranya.

3. Siswa bersikap tertib di dalam kelas.

\section{Aspek psikomotorik}

Aspek psikomotorik merupakan kategori yang terakhir dalam sebuah pembelajaran pendidikan yang didasarkan oleh Kurikulum, seperti menurut Elizabeth Stimpson, 1966 (Oemar Hamalik, 2015) sebagai berikut:

1. Persepdi (perception), penggunaan lima organ indra untuk memperoleh kesadaran tentang tujuan dan untuk menerjemahkannya menjadi tindakan (action). Contohnya: ketika bermain volley ball, siswa menggunakan penglihatan, pendengaran dan stimulus untuk menyadari unsur-unsur fisik dari pada permainan itu. 
2. Kesiapan, dalam keadaan siap untuk merespon secara mental, fisik dan emosional. Contohnya: seorang siswa menunjukan persiapan fisik dan sikap untuk melakukan kegiatan, misalnya siap star berenang.

3. Respon terbimbing, bantuan yang diberikan kepada siswa melalui pertunjukan peran model, misalnya setelah guru mendemonstrasikan suatu bentuk tingkah laku, lalu siswa mempraktikannya sendiri.

4. Mekanisme, respon fisik yang telah dipelajari menjadi kebiasaan misalnya menunjukkan keterampilan kerja kayu setelah mengalami pelajaran sebelumnya.

5. Respon unik, suatu tindakan motorik yang rumit dipertunjukkan dengan trampil dan efesien. Misalnya: setelah siswa latihan mengetik, maka dia dapat melaksanakan tugas-tugas yang ditentukan secara lengkap tanpa kesalahan dan dengan kecepatan tinggi.

6. Adaption, mengubah respon-respon dalam situasi-situasi yang baru. Misalnya: setelah mempelajari bermain basket ball, siswa menerapkan keterampilanketerampilan yang telah dipelajari itu dalam bermain basket di air.

7. Originasi, menciptakan tindakan-tindakan baru. Misalnya: setelah menyelesaikan pelajaran cara terjun kedalam kolam, siswa menciptakan cara-cara terjun baru dengan mengkombinasikan keterampilan yang telah dipelajari dengan eksperimen fisik.

Dalam pengimplementasiannya aspek psikomotorik ini lebih kedalam praktik siswa, seberapa mampu iya memahami pengetahuan dan nilai yang telah berlaku dalam pembelajaran dan sejauh mana siswa menjalankannya. Siswa cenderung lebih senang dalam aspek psikomotor ini karena hal ini cenderung lebih terbuka dan tidak terlalu mematokan siswa ataupun memaksakan siswa.

Keterampilan khusus yang menonjol memberikan nilai plus untuk siswa dan lebih terlihat akan kemampunya dalam segala hal, saat peneliti melihat kejadian dilapangan yaitu seperti halnya saat siswa sedang berolah raga, tentunya ada beberapa siswa yang mahir melakukan olahraga tersebut dengan taktik khususnya siswa itu melihatkan keahlian bidang olahraganya. 


\section{Pemahaman guru dan siswa tentang Kurikulum 2013}

Kurikulum 2013 ini memanglah banyak sekali aspek yang harus dijalankan serta ditekankan, karena K13 ini merupakan rombakan dari Kurikulum yang lainnya serta dengan adanya perkembangan zaman yang lebih modern yang memicu siswa untuk lebih memiliki keaktifan serta lebih menjadikan siswa ini untuk lebih mengetahui dan memahami segala ilmu pengetahuan yang ada.

Dari segi pemahaman tentunya bersangkutan dengan hal pengetahuan dan tidak semua guru dapat memahami kurikulum ini. Mengimplementasi kan aspek kurikulum sulit untuk mencapai angkat 100\% karena pemahaman seseorang itu tidak dapat diukur dan diperkirakan. Berdasarkan hasil penelitian bahwasannya guru dalam memahami dan kurang memahami dari Kurikulum 2013 ini ialah:

1. Metode pembelajaran, metode ini merupakan aspek ide kreatif yang dimiliki oleh guru untuk menuangkan ilmu dalam pembelajarannya.

Metode pembelajan itu sendiri meliputi

a. Metode ceramah : yang dimana metode ceramah ini dalam menyampaikan informasi pembelajaran kepada siswa dilakukan secara lisan metode ini cocok digunakan ditempat dengan jumlah pendengaran yang cukup besar dan memiliki keunggulan yaitu murid dapat dengan mudah dan cepat menerima informasi yang disampaikan guru, namun dalam hal ini mudah dilupakan. Suprayekti (2003:32).

b. Metode Diskusi

Metode pembelajaran ini merupakan berkaitan dengan suatu pemecahan masalah yang cocok diterapkan pada kelompok yang berjumlah tidak terlalu banyak.

c. Metode Tanya Jawab

Metode yang satu ini adalah suatu cara untuk menyampaikan pelajaran sekolah dengan cara seorang guru memberikan pertanyaan kepada muridnya. Selain itu, metode ini dilakukan untuk melihat sejauh mana pemahaman murid terhadap materi-materi yang disampaikan guru. Mulyatiningsih (2011:224).

d. Metode Demonstrasi

Metode demonstrasi ini metode dengan menggunakan benda, alat, ataupun bahan-bahan informasi yang dapat memberikan gambaran yang nyata. Selain itu untuk memperjelas informasi juga bisa dengan bentuk peraktikum mengenai materi yang disampaikan. 
e. Metode Latihan

Metode latihan atau drill adalah metode yang dapat digunakan untuk menyampaikan materi pelajarana atau sebuah informasi melalui bentuk latihan lainnya.

f. Metode perencanaan merupakan metode untuk mengajarkan sebuah perencanaan kepada siswa dalam bentuk diskusi.

Tidak banyak guru yang paham akan metode pembelajaran tersebut. seperti peneliti ketika meneliti di SMP ASSYFA, melihat saat dan mewawancarai guru dan mendapatkan hasilnya yaitu bahwa tidak semua guru menerapkan hal tersebut dan paham akan hal tersebut.

Bahkan kebanyakan guru menggunakan metode ceramah karena lebih dan mudah untuk diimplementasikan dalam pembelajaran.

\section{Hambatan sekolah}

Dalam suatu intansi yang memiliki tata tertib dan aturan pasti memiliki hambatan dalam segi apapun termasuk dalam lingkungan sekolah. Hambatan dalam melakasanakan implementasi kurikulum ini ialah sebagai berikut:

a. Kurangnya fasilitas yang memadai untuk melaksanakan kurikulum.

b. Siswa yang cenderung masih memiliki sikap pasif

c. Guru yang belum siap $100 \%$ dalam menjalankan sebuah kurikulum baru

\section{KESIMPULAN}

Dalam setiap aspek pendidikan terutama dalam sistem kurikulum tentunya akan selalu berubah, namun dalam sebuah perubahan hendaklah melihat dari segi sudut pandang lainnya. Terutama dalam sekolah yang lebelnya yayasan, yang dimana sistem dalam pembangunan serta fasilitas yang harus dipenuhi akan dititik beratkan kepada pemilik yayasan. Sehingga jika mesamaratakan sebuah sistem pendidikan di yayasan tersebut dengan pendidikan yang sudah cukup dalam pemenuhan apapunnya itu akan sulit. 


\section{DAFTAR PUSTAKA}

Abu Ahmad, 2016. Sosiologi pendidikan. Jakarta. Rineka cipta.

Tesniyadi Dema, M.Pd, 2018. Pengelolaan pendidikan. Yogyakarta, Samudra Biru.

Hamalik Oemar, 2015. Kurikulum dan pembelajran. Jakarta. Bumi aksara.

Hidayat Rahmat, 2013 Pengantar sosiologi kurikulum. Jakarta. Rajawali.

Kemendikbud, 2014. Implementasi Kurikulum 2013. Jakarta: Kementrian Pendidikan dan

Kebudayaan RI.

Mulyatiningsih, Endang. 2011. Penelitian Terapan. Yogyakarta. UNY Press.

Suprayekti. 2003. Interakasi Belajar Mengajar. Jakarta. Depdiknas.

Wayan Suwendra, 2018. Metodologi penelitian kualitatif dan ilmu sosial, pendidikan

kebudayaan, dan keagamaan. Badung. Dewa Nyoman Naraya Persada. 